\title{
AN EXPEDITION TO THE TANA RIVER, KENYA COLONY
}

\author{
By H. E. Percy, R. C. Percy, and M. W. Ridley
}

Our expedition to the Tana was a prelude to five months spent collecting birds and other small vertebrates of various kinds in Kenya and Uganda.

The Tana River, fed by numerous streams from the high ground in the region of Mt. Kenya, first flows east, then curves away south to reach the Indian Ocean at Kipini. Though it runs for most of its course through the arid semi-desert country of eastern Kenya, its up-country tributaries, under a more temperate climate, maintain it as a great river the whole year through.

We had two landrovers and a three-ton truck. These took us without mishap on the road and tracks near the river down its eastern bank. In this country the roads are only open in the dry seasons. They were very bumpy and dusty, and to cover a hundred miles in a day was tiring. Occasionally sand rivers had to be crossed. These sand-filled channels become transformed into rushing torrents for only short times during rain. Since the roads run straight across them, often without bridges of any kind, they may present real obstacles, if repairs have not been carried out since the last flood. At other times the road ran through patches of black cotton soil. It was then badly rutted and, at the coast, was often slippery. Conditions were similar on our return journey up the opposite side of the river.

The area is well known for its big game, the ivory being amongst the finest in Africa. We saw several elephant, many reticulated giraffe (on one occasion about forty together), zebra, and various species of antelope. Of the latter, dik-dik and gerenuk were most often seen. There were numbers of hippo at the mouth of the Tana.

The smaller vertebrates are, however, much less well known, and in order to find them and determine their species somewhat laborious methods of collecting are essential. As yet the ecology of these has been little studied in Africa.

We set out on the 7th August, 1951, and entered the Northern Province at Isiolo, completing a few formalities at the Provincial Commissioner's office on the way through. Since we were back in Nairobi by the 5th September, there was little time to deal 
with such a vast area and, except for a week spent at a group of water-holes at Ijara, we had to move pretty frequently.

The first camp was set up by a small stream, the Ngaramara River, near Isiolo. The country here (acacia-tall grass savanna) is well known for its comparatively large population of game birds. We never saw them in comparable quantities elsewhere and it seemed that the large flocks of francolin and helmeted guinea-fowl bore witness to an adequate closed season, although some may breed in the open season.

Much of the ground consisted of lava flows derived from volcanic mountains to the south. These flows, being of comparatively recent origin, formed outcrops in which rock hyrax were living. They would rapidly disappear if disturbed but they could be observed quite easily from a car, and we saw several young ones. These animals, now enjoying complete protection, were previously exploited for their fur. Ground squirrels were also common and often used to take refuge in termite mounds when pursued. It is possible that this may become a cattle country, for construction of bore-holes for water has been considered.

As we moved east the country became progressively more arid. We saw a few ostrich and then baboons running about on a great inselberg of gneis by the side of the road. Nearing Garba Tula, the road passed over some gypsum deposits which caused a most annoying dust and we were thankful to be able to spend the night there in a government rest-house.

Next day we turned south through the most lonely bush imaginable to reach the Tana at Saka. In these reaches the river is bordered generally by a strip of trees from one to 400 yards wide with thick undergrowth beneath. Here the latter had been largely removed presumably by goats from the village. The tree fringe gives way to arid bush which was then largely leafless, through a transition zone mainly composed of a light green leaved shrub (Salvadora persica L.). The Tana therefore provides a thread of life in this waste and supports a larger population of birds and other animals than the bush.

The river itself hardly looks refreshing, for it is a rich brown in colour, a testimony to the erosion that is prevalent in eastern Kenya. Seasonal flooding creates extensive sandbanks upon which the crocodiles lie out. It is said that these beasts grew fat on the bodies of slaves who perished on their way down the river to the arab slave stations on the coast.

We made our second riverside camp at Sankuri, a wateringplace some miles upstream of Garissa. Here to a sandy beach 
the Somalis brought their flocks; for they contrive to keep camels, cattle, sheep, and goats where any patch of grazing can be found.

The first night an elephant came down to drink in the moonlight but hearing us he turned and lumbered silently away.

There is a remarkable lizard population on the Tana. There were several species and their numbers were much greater than we saw anywhere else. They have the advantage of being easy to see, for they like to lie out in the heat of the day when other animals have disappeared into shaded retreats. We found the aquatic forms (which slithered into the water so quickly when disturbed that they could easily be mistaken for crocodiles), to belong to two species of monitor. It seems likely that they feed chiefly on frogs which are very abundant on the river bank. Elsewhere in Africa they are said to take crocodiles' eggs and they probably feed on anything they can catch. They are formidable creatures for we came across one that was over 4 feet long.

There were agamas also, both terrestrial and arboreal forms. Agama agama lionotus with bright blue body and yellow-golden head was a wonderful sight sunning itself. We saw one specimen that must have been about 2 feet long. This species was very difficult to get near to but it was quite common and used to lie out on the fallen trunks of trees as well as in the trees themselves. Two less spectacular species were also common. It seemed that the agamas were chiefly insectivorous but they may not be entirely so.

Striped skinks were found in the trees and bushes. These are a group of lizards with reduced legs. They seemed to feed exclusively on the abundant insect life. Many of them were breeding at the time. Geckos were also very common. They often occur in houses in the tropics and are noted insect feeders. They might be found in any tree or bush and we sometimes found their eggs.

Perhaps the most conspicuous birds were the starlings, the ubiquitous superb starling and the golden-breasted taking pride of place. Several other species of this family occurred and there were four or five species of dove that were extremely common. These made constant journeys to the water's edge and enlivened the air with their cooing.

Some smaller species of hornbill were well represented. There were many other species too numerous to name here but outstanding were buffalo weaver, collared sunbird, go-away bird, and crested francolin. Amongst the most exotic was the golden 
pipit whose brilliant yellow colouring when on the wing could be seen all down the lower Tana.

Small mammals were much less obvious than birds, but monkeys being diurnal were quite often seen. To these we might add hyrax, hare, and squirrel ; but for the smaller forms, it was necessary to sally forth at night, to set traps, and to smoke out holes in hollow trees. A set of ordinary mousetraps was excellent for many forms but the smoking out of holes was greater fun. One never knew what might come out. We were on our guard for snakes, especially the black mamba, but none were ever found in holes. From one tree we successfully extracted by this method a family of black-tailed tree rats, a gecko, some vicious-looking ants, and two large bloodsucking bugs.

A friend was able to accompany us for the first few days and he obtained a living naked mole rat, a strange rodent with mole-like burrowing adaptations.

At Sankuri we obtained a bush baby. These attractive little mammals, related to the lemurs, are quite common on the banks of the Tana. Amongst our collection were shrews, bats, rats, mice, and gerbils. The latter were often to be seen hopping about in the headlights of the cars. Small animals of these kinds tend to escape notice and our knowledge of them is very limited. Although identification must be reserved for experts, there is much work that anyone can do, who has time and access to these parts, for their biology and number fluctuations are very little known and few collections have been made.

Ijara, our next halt, some 120 miles to the south-east, is not on the Tana River, but its interest to us lay in its four water-holes which, intended for the use of the Somalis, support a varied population of aquatic animals. Some of the waterholes dry up from time to time, but in all there were quantities of lung-fish. These can resist drought by forming cocoons in the mud and breathing air. They come up for air when living in the water and sometimes make a curious gasping noise when held in the hand. It seems that they could have arrived in these rather isolated water-holes as larvæ, for in the past shoals of little fish have been seen in flood-water in the neighbourhood. Larvæ, which were present in the water-holes when we were there, have external gills and look rather like newt tadpoles, till one notices the wispy nature of their paired fins and tail.

The water-bird population was especially interesting because it was possible to make a fairly accurate census. Apart from a few other species there seemed to be at that time about a dozen 





heron belonging to six species, some moorhen, duck, and a few waders. The surrounding bush was very highly populated with birds, especially doves and magpie starlings, which paid frequent visits to the water. The Juba little purple-banded sunbird was nesting here. Vulturine guinea-fowl were common.

From Ijara we moved to Kipini at the mouth of the Tana. Soon after leaving we passed through more wooded country which changed rather imperceptibly into dom-palms, high grass, and swamps with beautiful water-lilies. The road was often under water and had been closed for several months because of the previous excessive rains. On one occasion the lorry stuck but we pulled it out successfully with the landrovers and just as it got dark we reached Kipini, to the surprise of the District Commissioner, who gave us a great welcome.

Next morning from our camp on the sand dunes we overlooked the Tana on its last stage where, coffee coloured, it pours itself into the Indian Ocean. With great kindness the D.C. suggested two trips for us and arranged a boat.

The first trip took us up the river, for in its lower reaches there are dense forested swamps. Here we saw wood-ibis, hammerkop, and many sorts of heron. In addition there were large flocks of pink-backed pelican. On the tide-line there were curlew (whose call reminded us of England), Caspian tern, sooty gull, and many small waders. On one occasion during a heavy rainstorm we obtained a specimen of the Aldabra frigate bird. The frigate birds are an oceanic group and this bird, an immature specimen, had probably been driven ashore by the gale. It is a first record for Kenya Colony.

The second trip was to the Ziwaiu Islands, a little further up the coast. We left in a dhow at about 8 a.m. It was rather rough and we did not arrive till about noon. There was some difficulty in getting out of the river for the tide was coming in but eventually we set sail, though several times we were nearly pitched out of the boat to the great amusement of the crew.

The islands comprise a few remnants of much weathered limestone sticking up sometimes as much as $\mathbf{1 5}$ feet above a coral-encrusted marine platform of the same material. Their sides are jagged and abrupt and those we examined were about 100 yards in length. We did not visit all of them but could see them all with ease. Most were bare but on a few of the higher ones there were bushes.

We paddled for about an hour upon the platform and in places we found little beaches composed of coral fragments. The pools were very beautiful with their exotic coloured fishes, 
crabs, and giant "Coat of Mail" shells (Chitons). We saw another boat moored close by and then some fishermen drying shark meat by the side of a temporary hut. It seemed strange that we saw no sea birds here.

We did collect one species of skink. This was abundant but very difficult to catch. It did not take refuge in the sea but hid in crannies in the rocks.

Our escort, having collected a pail full of oysters, a kind with crinkled shells, which were so deeply embedded in the rock that they had to be extracted with a hammer, indicated that the tide was coming in. So, setting sail, we made a much more rapid journey home and enjoyed the oysters in the evening.

After three days at Kipini we were told that the ferry at Garsen was operating. This was of great importance because it made it possible to return by a different route. We hoped by nightfall to reach a point a little short of Bura on the opposite side of the river, but getting badly stuck before the ferry we were well short of this as night set in. Seeing no convenient camping site to hand we took an earlier turning to the river.

Here at Wenje the surroundings were very different from what we had seen before because there was much cultivation at the expense of the forest fringe. The villagers (the Galla Tribe) cultivate coconuts, rice, limes, cotton, millet, and bananas, and it seems that these lower reaches of the Tana may become very rich if flooding problems can be overcome. As would be expected, birds were very plentiful and there were many that we had not seen before. We caught an elephant shrew hopping about in the darkness and there was much noise from bush babies though we saw none. For the first time we were really troubled with mosquitoes.

This had to be our last collecting place, and after spending two nights in this village regretfully we turned for home.

\section{VERTEBRATES OF THE TANA SPECIALLY MENTIONED IN THE TEXT}

Frshes

African Lung-Fish (Protopterus amphibius (Peters). This species requires redescription and will be the subject of a future publication).

Frogs and Toads

Rana mascareniensis Duméril and Bibron. Common at Ijara.

Rana oxyrhynchus A. Smith. Common on the banks of the Tana.

Arthroleptis minutus Boulenger. Common at Ijara.

Bufo regularis Reuss. A common toad in suitable localities.

Montor Lizards

NiLe Monitor (Varanus niloticus niloticus (Linn)). Common.

Bosc's Monrtor (Varanus exanthematicus microstictus Boettg.). A specimen 4 feet long obtained by Lieut.-Col. C. H. Stockley at Sankuri. 


\section{An Expedition to the Tana River, Kenya Colony}

Agamas

Common Agama (Agama a. agama (Linn)).

Agama a. lionotus Boulenger. Especially well represented at Saka and Sankuri. Agama atricollis Smith. A specimen obtained at Kipini.

\section{SkINks}

Striped Skink (Mabuya striata (Peters)). A very common skink. Many specimens contained embryos.

Ablepharus boutoni africanus Sternf. We found this species on the Ziwaiu Islands, where it was plentiful. It would seem that this population must be entirely isolated from the mainland.

\section{Geckos}

All common in suitable localities.

Hemidactylus mabouia Mor.

Hemidactylus brookii Gray.

Hemidactylus ruspoli Boulenger.

\section{Guinea-fowl, Spurfowl, and Francolin}

Reichenow's Helmeted Guinea-fowl (Numida mitrata reichenowi O. Grant). Common near Isiolo but was replaced by the next species as we moved further east.

Vulturine Guinea-fowl (Acryllium vulturinum (Hardwicke)). This and the above make a valuable contribution to the pot.

Yeldow-necked Spurfowl (Pternistis leucoscebus infuscatus Cab.). Common. Other species were less in evidence.

Red-Necked Spurfowl (Pternistis cranchii leucoparaeus (Fisch. and Reichnw.)). Common on Lower Tana.

Crested Francolin (Francolinus sephaena grantii Hartl.). Numerous and breeding at Ijara.

\section{STARLINGS}

Superb Starling (Spreo superbus (Rupp.)).

Golden-breasted Starling (Cosmopsarus regius Reichnw.).

MagPie Starling (Speculipastor bicolor Reichnw.).

\section{Doves}

The following were constantly seen but others were also identified :-

RrNG-NeCked Dove (Streptopelia capicola tropica (Reichnw.)).

RED-EYED Dove (Streptopelia semitorquata semitorquata (Rupp.)).

Laughing Dove (Stigmatopelia senegalensis (Linn.)).

EMERALD-SPOTTED WOOD-DOve (Turtur chalcospilos chalcospilos (Wagler)).

\section{HoRNBILLS}

Grey Hornbili. (Tockus nasutus nasutus (Linn.)). Common at Ijara. Van der Decken's Hornaile (Tockus deckeni (Cab.)). Quite common.

RED-BILLED HORNBILL (Tockus erythrorhynchus erythrorhynchus (Temm.)).

\section{WEAVERS}

Buffalo Weaver (Bubalornis i. intermedius (Cab.)).

Abyssinian Masked Weaver (Ploceus i. intermedius (Cab.).

\section{SUNBIRDS}

Collared Sunbird (Anthreptes collaris elachior Mearns).

Juba LitThe Purple-banded Sunbird (Cynnyris chalcomelas (Reichnw.). This generally rare sunbird was common at Ijara. Nests and eggs hitherto undescribed were found. 
At Ijara :-

Herons

Buack-headed Heron (Ardea melanocephala Vigors \& Children).

Squacco Heron (Ardeola ralloides (Scopoli)).

GreEN-BACKed Heron (Butorides striatus atricapillus (Afz.)).

Great White EgRet (Casmerodius albus melanorhynchos (Wagl.)).

Yellow-BILled EgRET (Mesophoyx intermedius brachyrhynchos (Brehm.)).

Night Heron (Nycticorax n. nycticorax (Linn.)).

At the mouth of the Tana, the last three mentioned above and several other species, including :-

LitTle Egret (Egretta garzetta garzetta (Linn.)).

\section{At Ijara :-}

\section{WADERS}

Common SANDPIPER (Tringa hypoleucos (Linn.)).

WoOD SANDPIPER (Tringa glareola Linn.).

Green SANDPIPER (Tringa ocrophus Linn.).

At Coast :-

Terek SandpIPer (Xenus cinereus (Güldenstädt)). A few seen.

Curlew (Numenius arquata (Linn.)). Fairly common.

\section{OTHER Birds}

Go-AWAY BIRD (Corythaixoides leucogaster (Rupp.)).

Golden Pipit (Tmetothylacus tenellus Cab.).

LESSER MOORHEv (Gallinula angulata Sundevall).

White-faced TREe-DUCK (Dendrocygna viduata (Linn.)).

The only ducks seen were thirteen of this species at Ijara.

WOOD-IBIS (Ibis ibis (Linn.)).

HAMMERKOP (Scopus umbretta bannermani C. Grant).

Pink-Backed Pelican (Pelecanus rufescens Gmelin).

Caspian Tern (Hydropogne caspia caspia (Pall.)).

Sooty Gull (Larus hemprichii (Bruch.)).

Aldabra Frigate Bird (Fregata minor aldabrensis Math.). New record for Kenya.

\section{Small Mammals}

Rock Hyrax (Heterohyrax brucei Gray).

Eiast African Ground Squinrel (Xerus rutilus rufifrons Dollman).

Bush SQUiRRel (Paraxerus ochraceus ganana Rhoads). This small arboreal squirrel is found in the tree fringe along the river.

East African Hare (Lepus raineyi Heller).

Naked Mole Rat (Heterocephalus glaber ssp). A specimen obtained by Lieut.-Col. C. H. Stockley at Sankuri.

Black-tailed Tree-Rat (Thallomys damarensis scotti Thos. \& Hinton).

DoRmouse (Claviglis parvus True).

SPINy Mouse (Acomys ignitus kempi Dollman, and Acomys wilsoni ablutus Dollman). Seldom seen but appeared quite common at Ijara.

GerBIL (Taterillus nubilus illustris Dollman).

Baboon (Papio doguera ssp).

Green or Swamp Monkey (Tumbili) (Cercopithecus athiops johnstoni Pocock). We saw this species of monkey most frequently.

Bush BABY (Galago senegalensis gallarum Thomas). In the tree fringe along the Tana.

White-Toothed Shrew (Crocidura macarthuri St. Leger). This was the second specimen of this species known. It was obtained at Ijara.

Rock or Spectacled Elephant Shrew (Elephantulus dundasi Dollman). Found at Wenje.

Hollow-Faced Bat (Nycteris aurita $\mathrm{K}$. Anderson). 
White-beldifed Free-tarled Bat (Chaerephon limbalus (Peters)). This and the above species were common at Ijara.

Lesser Yellow BAT (Scotophilus viridis viridis (Peters)). At Kipini. This does not appear to have been recorded from Kenya before.

\section{ACKNOWLEDGments}

The authors wish to express their sincere thanks to Lieut.-Col. C. H. Stockley, D.S.O., O.B.E., M.C., to Mr. R .A . Palmer (then District Commissioner at Kipini), to Mr. and Mrs. A. Dorman, to the Staff of the Coryndon Museum, Nairobi, to the Kenya Game Department, and to the Staff of the British Museum (Natural History), all of whose help was invaluable.

\section{REFERENCES}

COPLEY, H., 1950. Small mammals of Kenya. Nairobi.

EDWARDs, D. C., 1940. A vegetation map of Kenya. With particular reference to Grassland Types. Journal of Ecology, 28, 377.

JAckson, F. J. J., 1938. The Birds of Kenya Colony and the Uganda Protectorate. London.

Mackworth-Pread, C. W., and Grant, C. H. B., 1952. Birds of East and Central Africa. London.

Percy, H. E., Percy, R. C., and Ridley, M. W., 1953. The Water-holes at Ijara, Northern Province, Kenya. Journal of the East Africa Natural History Society. In Press.

Swynnerton, G. H., and Hayman, R. W., 1950. A check list of the Land Mammals of the Tanganyika Territory and the Zanzibar Protectorate. Journal of the East Africa Natural History Society, 20, Nos. 6 and 7 (90). 